\title{
Phylogenetic relationships among Armillaria species inferred from partial elongation factor 1-alpha DNA sequence data
}

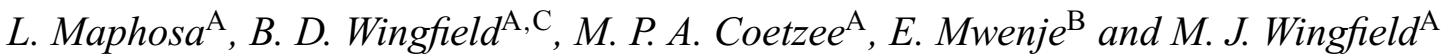 \\ ${ }^{A}$ Department of Genetics, Forestry and Agricultural Biotechnology Institute, \\ University of Pretoria, Pretoria, South Africa. \\ ${ }^{B}$ Department of Applied Biology and Biochemistry, National University of Science and Technology, \\ PO Box AC 939, Ascot, Bulawayo, Zimbabwe. \\ ${ }^{\mathrm{C}}$ Corresponding author. Email: brenda.wingfield@fabi.up.ac.za
}

\begin{abstract}
Armillaria species are important root rot pathogens with a wide host range and a worldwide distribution. The taxonomy of these fungi has been problematic for many years but the understanding of the relationships between them has been substantially improved through the application of DNA sequence comparisons. In this study, relationships between different Armillaria species were determined using elongation factor 1-alpha DNA sequence data for the first time. A total of 42 isolates, representing the majority of Armillaria species, with diverse geographic distributions and hosts, were included in this study. PCR amplification yielded products of $600 \mathrm{bp}$ for all the isolates. Phylogenetic trees resulting from parsimony analysis showed that this gene region is useful for studying relationships between species. Generally, results were similar to those emerging from previous comparisons using ITS and IGS-1 sequence data. Phylogenetic trees generated from the dataset grouped the African taxa in a strongly supported clade, basal to the rest of the Armillaria species included in the study. The Armillaria species originating from the Northern Hemisphere formed a monophyletic group. Within this group, isolates of A. mellea constituted four subclades, representing their geographical origin. The phylogenetic relationships among species from the Southern Hemisphere were not entirely resolved. However, A. pallidula, A. fumosa and A. hinnulea grouped in a strongly supported clade and isolates of $A$. limonea formed a sister clade with those of $A$. luteobubalina. This is the first time a single-copy protein coding gene has been used to study phylogenetic relationships in Armillaria, and overall the data support previously held views regarding the relationships between species.
\end{abstract}

Additional keywords: Armillaria root rot, EF 1- $\alpha$, evolution, basidiomycetes, Tricholomataceae, taxonomy.

\section{Introduction}

Species of Armillaria are important plant pathogens that can cause serious root disease problems in plantations, natural forests and in fruit tree orchards. These pathogens cause the plant disease known as Armillaria root rot. The taxonomy of Armillaria has been surrounded by considerable confusion and debate. The taxonomic status of Armillaria is, however, now reasonably well recognised and there are at least 38 species included in the genus, based on morphological characteristics or reproductive isolation (Volk and Burdsall 1995).

A number of techniques have been employed to identify Armillaria species. Traditionally, macro- and micromorphological characters of the basidiocarps were used for this purpose. Although this method is reasonably easy to apply, the rare occurrence of basidiocarps and their relatively short-lived nature, limits the use of morphology for identification (Swift 1972; Kile and Watling 1981). In addition to these problems some species, for example A. gemina and A. ostoyae, have identical basidiocarp morphologies (Bérubé and Dessureault 1989). These limitations led to the introduction of mating compatibility tests to facilitate identification (Korhonen 1978; Ullrich and Anderson 1978; Anderson and Ullrich 1979). This method is, however, time consuming and results are commonly ambiguous. Yet, despite their disadvantages morphology and mating tests have played an important role in Armillaria taxonomy and are still commonly used.

In an attempt to overcome the problems associated with morphology and mating compatibility tests, identification employing biochemical and genotypic characteristics have emerged. Biochemical characters obtained from isozyme and protein profiles (Morrison et al. 1985; Lin et al. 1989; Whalström et al. 1991; Mwenje and Ride 1996) as well as 
monoclonal and polyclonal antibodies (Burdsall et al. 1990) have been used. Genotypic characters from mtDNA, nDNA and amplified IGS-1 as well as ITS region RFLP analyses (Anderson et al. 1989; Harrington and Wingfield 1995; Coetzee et al. 2000b), DNA-DNA hybridisation (Miller et al. 1994) and AFLP (Pérez-Sierra et al. 2004) have yielded useful results.

Comparisons of DNA sequence data are increasingly being used in order to gain knowledge concerning the phylogenetic relationships among Armillaria species. Sequence data for this purpose have largely emerged from the IGS-1 (Anderson and Stasovski 1992; Coetzee et al. 2000a, 2000b, 2001; Pérez-Sierra et al. 2004) and ITS regions (Coetzee et al. 2000a, 2001; Chillali et al. 1998; Pérez-Sierra et al. 2004). Piercey-Normore et al. (1998) used combined sequence data of four anonymous DNA regions to determine the phylogeny of North American biological species (NABS) of Armillaria. The combined anonymous dataset gave a more resolved phylogenetic tree than those based on ITS and IGS-1 sequence data. No studies have been reported employing DNA sequence data for a protein-coding gene for phylogenetic analyses including a wide variety of Armillaria species.

The objectives of this study were to generate DNA sequence data for the translational elongation factor $1-\alpha$ (EF 1- $\alpha$ ) gene for Armillaria spp. from different parts of the world. This gene is involved in protein synthesis in eukaryotes, transporting amino-acyl tRNAs to the ribosomes (Slobin 1980). It has been successfully used in taxonomic and phylogenetic studies on ascomycetes and basidiomycetes, both at the intra- and interspecific levels (Baayen et al. 2000; Kauserud and Schumacher 2001; Jiménez-Gasco et al. 2002). Data from the current study would provide an additional gene region on which to test taxonomic groupings and phylogenetic relationships previously identified using other gene regions.

\section{Materials and methods}

Cultivation of isolates

Isolates included in this study were obtained from the culture collection (CMW) of the Forestry and Agricultural Biotechnology Institute (FABI), University of Pretoria, South Africa (Table 1). Isolates were grown on MYA ( $2 \mathrm{~g} / \mathrm{L}$ Biolab malt extract, $0.2 \mathrm{~g} / \mathrm{L}$ Biolab yeast extract and $1.5 \mathrm{~g} / \mathrm{L}$ Biolab agar) in Petri dishes for two weeks at $23^{\circ} \mathrm{C}$ in the dark.

\section{DNA extraction}

Isolates were transferred to liquid MY $(2 \mathrm{~g} / \mathrm{L}$ Biolab malt extract and $0.2 \mathrm{~g} / \mathrm{L}$ Biolab yeast extract) in $500-\mathrm{mL}$ Erlenmeyer flasks and allowed to grow for three weeks at $23^{\circ} \mathrm{C}$ in the dark. Mycelium was harvested through filtration, freeze-dried and ground into a fine powder in liquid nitrogen. Approximately $0.6 \mathrm{~g}$ of powdered mycelium was added to $1 \mathrm{~mL}$ of extraction buffer $(200 \mathrm{~mm}$ Tris- $\mathrm{HCl}$, $\mathrm{pH} 8 ; 25 \mathrm{~mm}$ EDTA; $250 \mathrm{~mm} \mathrm{NaCl} ; 0.5 \%$ SDS) and incubated at $57^{\circ} \mathrm{C}$ for one hour. The aqueous phase was separated from cell debris by centrifugation $(15300 \mathrm{~g}, 30 \mathrm{~min})$. Phenol : chloroform $(1: 1)$ extractions were performed until a clean interphase was obtained Excess phenol was removed through a final chloroform extraction. DNA was precipitated overnight at $-20^{\circ} \mathrm{C}$ using cold ethanol $(2: 1 \mathrm{v} / \mathrm{v})$ and collected by centrifugation $(15300 \mathrm{~g}, 15 \mathrm{~min})$. The precipitated DNA was washed with $70 \%$ ethanol and recollected by centrifugation. The DNA was dried at $55^{\circ} \mathrm{C}$ and resuspended in sterile distilled water. DNA concentrations were determined using a Beckman Du Series 7500 UV spectrophotometer following the procedure outlined in Maniatis et al. (1982).

\section{Amplification of the partial EF 1- $\alpha$ gene region}

Approximately $100 \mathrm{ng}$ of DNA extracted from the Armillaria isolates was used as template for amplification of a region of the EF 1- $\alpha$ gene. Amplicons were generated using primers EF595F (5' CGT GAC TTC ATC AAG AAC ATG $3^{\prime}$ ), which binds at the $5^{\prime}$ end of the exon, and EF1160R (5' CCG ATC TTG TAG ACG TCC TG $3^{\prime}$ ), which is complimentary to the $3^{\prime}$ end of the exon (Kauserud and Schumacher 2001) (Fig. 1). The PCR reaction mixture included $1 \mathrm{~mm}$ of each dNTP; $2.5 \mathrm{mM} \mathrm{MgCl}_{2}$; PCR buffer supplied with the polymerase enzyme; $0.1 \mu \mathrm{M}$ of each primer; $100 \mathrm{ng}$ DNA and $2.5 \mathrm{U}$ of $\mathrm{Taq}$ polymerase (Boehringer Mannheim, South Africa). The final reaction volume was $50 \mu \mathrm{L}$. The PCR reaction conditions were: an initial denaturation at $94^{\circ} \mathrm{C}$ for $2 \mathrm{~min}$; 30 cycles of denaturation at $94^{\circ} \mathrm{C}$ for $30 \mathrm{~s}$; annealing at $56^{\circ} \mathrm{C}$ for $30 \mathrm{~s}$ and an extension step at $72^{\circ} \mathrm{C}$ for $30 \mathrm{~s}$. The final elongation step was allowed to proceed for $7 \mathrm{~min}$ at $72^{\circ} \mathrm{C}$. PCR products were electrophoresed on a $1 \%(\mathrm{w} / \mathrm{v})$ ethidium bromide-stained agarose gel and the bands were visualised under UV illumination.

\section{DNA sequencing}

PCR products were purified prior to sequencing using a QIAquick PCR purification kit (QIAGEN, Hilden, Germany). Primers EF595F and EF1160R were used in separate reactions to sequence both DNA strands. Sequencing reactions were conducted using a ABI PRISM Dye Terminator Cycle Sequencing Ready Reaction Kit with AmpliTaq DNA Polymerase, FS (Perkin Elmer, Warrington, UK) according to the manufacturer's instructions. DNA sequences for the partial EF 1- $\alpha$ gene were determined using an ABI PRISM 3100 automatic DNA sequencer (Applied Biosystems, Foster City, CA). Sequences were deposited in GenBank (Accession numbers: DQ435623-DQ435620).

\section{DNA sequence analysis}

Sequencing results were analysed using Sequence Navigator version 1.01 (ABI PRISM $\left.{ }^{\mathrm{TM}}\right)$. The DNA sequences were aligned using the program ClustalX, version 1.8 (Thompson et al. 1997) and manually adjusted. Phylogenetic analysis was performed using PAUP* version 4.0b10 (Swofford 1998). DNA sequences from the basidiomycete Schizophyllum commune (GenBank accession number X94913) were used to provide an outgroup. Missing and ambiguous characters were excluded from the analysis. Phylogenetic signal (Hillis and Huelsenbeck 1992) was determined for 1000 random trees. Phylogenetic trees were generated based on parsimony using heuristic searches with random stepwise addition of sequences (10 replicates) and TBR (tree bisection reconnection) branch swapping with MulTree active. Characters were reweighted according to the mean consistency index (CI) after each tree search until the number of trees stabilised, to reduce homoplasy. Confidence at the branch points was obtained through bootstrap analysis (1000 replicates) (Felsenstein 1985). Settings were the same as above except that simple addition of sequences was used.

\section{Results}

\section{DNA amplification}

A DNA amplicon was successfully amplified for all the isolates used in this study. All amplifications yielded a single 
Table 1. List of Armillaria isolates used in the study

\begin{tabular}{|c|c|c|c|c|}
\hline Species & Isolate number & $\begin{array}{l}\text { Alternative culture } \\
\text { collection number }\end{array}$ & Collector/Supplier & Origin \\
\hline \multirow[t]{2}{*}{ A. borealis } & CMW3172 & B370 & K. Korhonen & Finland \\
\hline & CMW3182 & B373 & K. Korhonen & Germany \\
\hline A. cepistipes & CMW6909 & $33 / 82144$ & D. Morrison & USA \\
\hline \multirow[t]{2}{*}{ A. fumosa } & CMW4955 & $123 / 1$ & C. Mohammed & Australia \\
\hline & CMW4960 & Q/COLL.9.4 & C. Mohammed & Australia \\
\hline \multirow[t]{2}{*}{ A. fuscipes } & CMW3164 & B933 & J. M. Sung & La-Reunion \\
\hline & CMW4953 & LR2 & C. Fabregue & La-Reunion \\
\hline \multirow[t]{2}{*}{ A. gallica } & CMW3171 & B110 & K. J. Smereka & USA \\
\hline & CMW6901 & $21 \mathrm{~A}$ & M. T. Banik & USA \\
\hline \multirow[t]{2}{*}{ A. gemina } & CMW3181 & B485 & J. Anderson & USA \\
\hline & CMW6888 & 5/JJW223 & J. J. Worrall & USA \\
\hline \multirow[t]{2}{*}{ A. hinnulea } & CMW4980 & 119/DAR & C. Mohammed & Australia \\
\hline & CMW4981 & LOT3/2 & C. Mohammed & Australia \\
\hline \multirow[t]{2}{*}{ A. limonea } & CMW4680 & C3.28/0.1 & I. A. Hood & New Zealand \\
\hline & CMW4991 & $3522 / 2$ & G. S. Ridley & New Zealand \\
\hline \multirow[t]{2}{*}{ A. luteobubalina } & CMW4977 & $\mathrm{SA}(6)$ & C. Mohammed & Australia \\
\hline & CMW8876 & Chile-1 & M. J. Wingfield & Chile \\
\hline \multirow[t]{9}{*}{ A. mellea } & CMW11265 & 426 & - & Italy \\
\hline & CMW3956 & B497 & J. Anderson & East USA \\
\hline & CMW3961 & $\mathrm{B} 730$ & T. Terashita & Japan \\
\hline & CMW3964 & B927 & T. Bruns & West USA \\
\hline & CMW4605 & B282 & T. C. Harrington & East USA \\
\hline & CMW4610 & B916 & J. M. Sung & South Korea \\
\hline & CMW4611 & B917 & J. M. Sung & South Korea \\
\hline & CMW4613 & B1205 & M. Saber & Iran \\
\hline & CMW4620 & B1218 & - & West USA \\
\hline A. nabsnona & CMW6905 & 28/HB-20/SS5 & D. Morrison & USA \\
\hline \multirow[t]{3}{*}{ A. novae-zelandiae } & CMW4722 & G3.0.34.4 & I. A. Hood & New Zealand \\
\hline & CMW4967 & NSW3(4) & C. Mohammed & Australia \\
\hline & CMW5448 & $7365 / 2$ & R. H. Petersen & Australia \\
\hline A. ostoyae & CMW3162 & B481 & J. Anderson & USA \\
\hline A. pallidula & CMW4971 & 3984 & C. Mohammed & Australia \\
\hline \multirow[t]{2}{*}{ A. tabescens } & CMW3158 & B898 & T. Volk & USA \\
\hline & CMW3165 & B531 & J.-J. Guillaumin & France \\
\hline \multirow[t]{2}{*}{ Zimbabwe Group II } & CMW4455 & 40 & E. Mwenje & Zimbabwe \\
\hline & CMW4456 & $\mathrm{Z1}$ & M. Ivory & Zimbabwe \\
\hline \multirow[t]{2}{*}{ Zimbabwe Group III } & CMW10115 & 56 & E. Mwenje & Zimbabwe \\
\hline & CMW9954 & $\mathrm{P} 21$ & E. Mwenje & Zimbabwe \\
\hline \multirow[t]{4}{*}{ Unknown } & CMW4143 & - & M. J. Wingfield & Indonesia \\
\hline & CMW4994 & $4698 / 10$ & G. S. Ridley & New Zealand \\
\hline & CMW5446 & $7348 / 10$ & R. H. Petersen & Argentina \\
\hline & CMW5597 & A $35-4$ & I. A. Hood & New Zealand \\
\hline
\end{tabular}

fragment. The amplification products for the isolates were $\sim 600$ bp in length.

\section{Sequence data and analysis}

The total number of characters included in the data matrix was 562 after alignment by inserting gaps. Twenty-five missing or ambiguously aligned characters and 329 constant characters were excluded from the analysis. The number of parsimony informative characters was 173. A $g 1$ value of -1.40443 was obtained, indicating that there was phylogenetic signal. Heuristic searches yielded eight parsimonious trees with a length of 462 steps. The CI and retention index (RI) were 0.680 and 0.852 , respectively. Five parsimonious trees were generated (length $=314$ steps, $\mathrm{CI}=0.787$ and $\mathrm{RI}=0.897$ ) after reweighting. Generally the trees had similar topologies but differed in branch length. One of the five most parsimonious trees (Fig. 2) was randomly chosen for presentation.

Bootstrap values supported the separation of species into distinct clades. In the analyses, two major and wellsupported groups were detected. One of these represented isolates from Africa ( $100 \%$ bootstrap support) and the other 


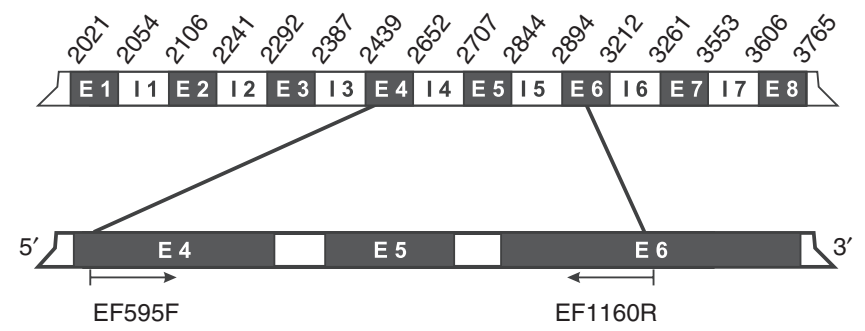

Fig. 1. Diagram showing the structure of the elongation factor $1-\alpha$ gene from the basidiomycete Schizophyllum commune. Exons and introns are presented with black and white boxes, respectively. The binding positions for primers EF595F and EF1160R are indicated on the enlarged diagram. The numbers indicate the positions of the bases in the EF $1-\alpha$ gene open reading frame of $S$. commune.

incorporated all isolates from other parts of the world. These are referred to as the African and non-African clades. The Northern Hemisphere species grouped within a wellsupported subclade ( $83 \%$ bootstrap support) within the nonAfrican clade.

Isolates within the African clade formed two subclades. Isolates CMW3164 and CMW4953 representing A. fuscipes grouped within one subclade with $74 \%$ bootstrap support. The remainder of the isolates CMW4455, CMW4456, CMW10115 and CMW9954 representing Zimbabwean groups II and III (Mwenje and Ride 1996) formed the second subclade with $99 \%$ bootstrap support. Isolates CMW9954 and CMW10115 formed a group within the second subclade with $63 \%$ bootstrap support.

Isolates representing $A$. borealis, $A$. gallica, A. nabsnona, A. cepistipes and $A$. tabescens grouped together in one clade with a $63 \%$ support value. This clade comprised three less well-supported clades, namely the $A$. borealis clade, A. tabescens clade and a clade comprising A. gallica, A. nabsnona, and A. cepistipes. Armillaria gemina and A. ostoyae grouped in a sister clade with $100 \%$ bootstrap support. These two major clades had $75 \%$ bootstrap support.

Isolates representing $A$. mellea formed a monophyletic group within the Northern Hemisphere clade. Isolates CMW3956 and CMW4605 from eastern North America formed a separate subclade with a 96\% bootstrap support value. Isolates CMW3964 and CMW4620 from western North America grouped together with 100\% bootstrap support. Armillaria mellea isolates CMW4613 and CMW11265 from Europe resolved into a clade with $100 \%$ bootstrap support. Isolates CMW3961, CMW4610 and CMW4611 from Asia formed a separate clade with $99 \%$ bootstrap support.

Southern Hemisphere isolates CMW4955 and CMW4960, representing A. fumosa, and isolate CMW4971, representing $A$. pallidula, grouped together with $100 \%$ bootstrap support. The clade with $A$. hinnulea isolates CMW4980 and CMW4981 had 100\% bootstrap support and formed a sister clade to A. fumosa and A. pallidula (78\% bootstrap support). Isolate CMW8876 of unknown identity grouped with A. luteobubalina isolates CMW4977 and CMW5446 (98\% bootstrap support). Armillaria limonea isolates CMW4680 and CMW4991 resolved into a clade with $100 \%$ support and formed a sister group to $A$. luteobubalina (98\% bootstrap support). Isolates CMW4967, CMW4722 and CMW5448 representing $A$. novae-zelandiae and CMW4143 representing an unknown species formed a clade with a bootstrap value of $100 \%$. Two isolates CMW4994 and CMW5597 of unknown identity formed a distinct subclade with $100 \%$ bootstrap support.

\section{Discussion}

DNA sequence data for the EF 1- $\alpha$ gene were successfully generated and analysed for a range of Armillaria spp. in this study. To the best of our knowledge, this is the first time that this gene region has been used to consider phylogenetic relationships in Armillaria. All isolates yielded PCR products of similar size, indicating that the amplified gene region does not include large indels, and is therefore a suitable choice of gene region for phylogenetic studies. The aligned sequences showed considerable homology among Armillaria spp. but various species-specific nucleotide substitution and indels were observed. Little sequence variation was observed within species with noticeable variation between different species. This is consistent with various previous studies employing IGS-1 and ITS rDNA operon DNA sequence data in taxonomic studies of Armillaria spp. (Anderson and Stasovski 1992; Chillali et al. 1998; Coetzee et al. 2001, 2003).

Phylogenetic comparisons based on EF 1- $\alpha$ sequence data showed that Armillaria spp. thought to be native to Africa, reside in a clade strongly separated from all other species. This so-called African clade has previously been identified based on isozyme analysis (Mwenje and Ride 1997) and IGS-1 sequence data (Mwenje et al. 2003). Thus, the sequence data for a new protein-coding gene region reflect the same patterns that have emerged from previous molecularbased comparisons.

Isolates from Africa that have previously been shown to represent different taxonomic groups (Mwenje et al. 2003) resided in a strong monophophyletic assemblage and are regarded as the African Armillaria group. These isolates were previously thought to represent a single species treated as A. heimii sensu lato and were shown to have high levels of intraspecific variation (Mohammed et al. 1989). Recent studies based on IGS-1 and ITS sequence data, however, suggest that the African isolates represent at least two different species: A. fuscipes (syn. A. heimii) and an unnamed species (Coetzee et al. 2000b; Mwenje et al. 2003; Coetzee et al.2005). Pérez-Sierra et al. (2004) reported similar results but viewed the two groups as different populations of A. fuscipes, which they referred to as $A$. heimii and an unknown species. Results of the present study also show that the African isolates reside in subclades, representing the three taxonomic groups suggested by Mwenje et al. (2003). 


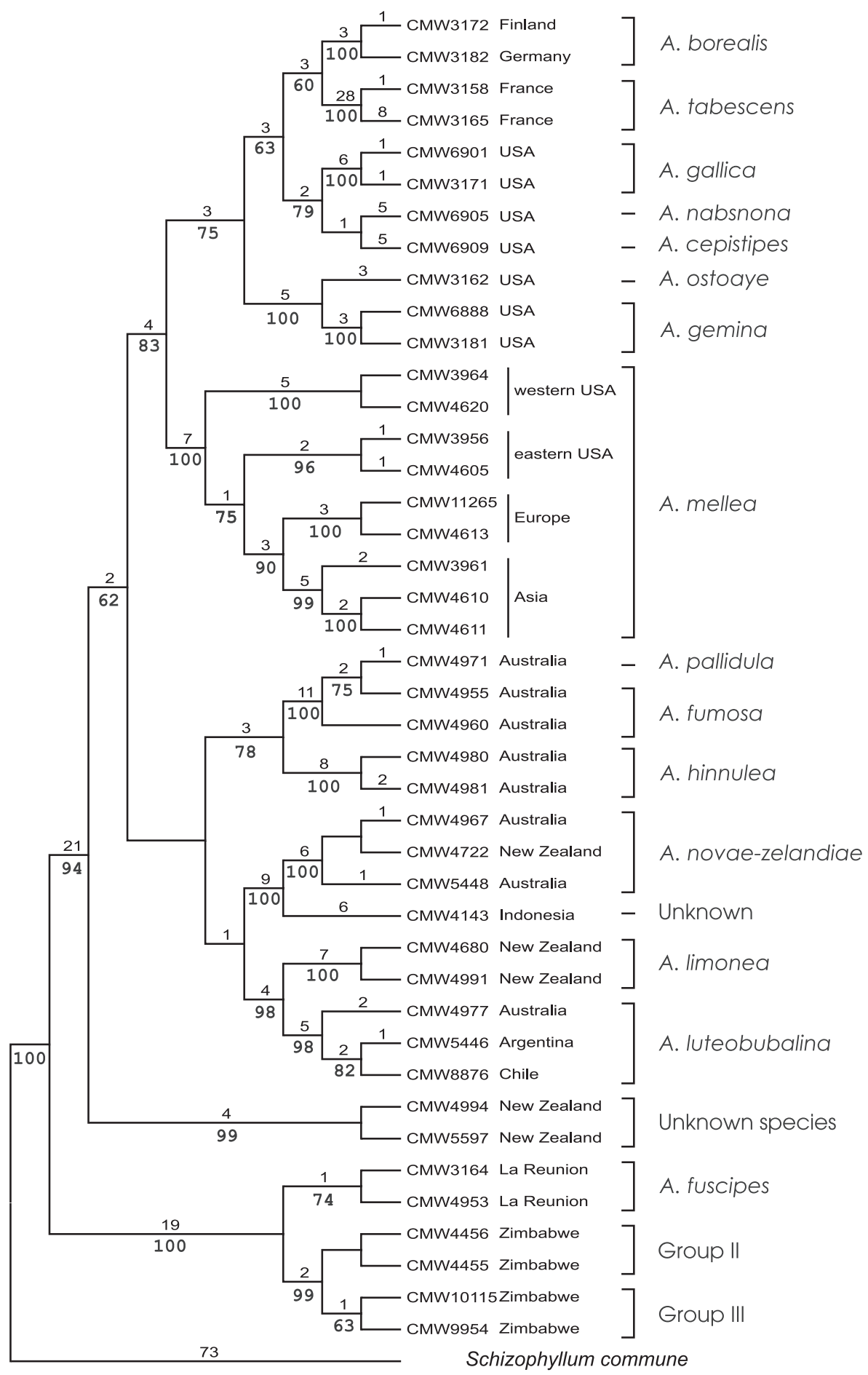

Fig. 2. One of the most parsimonious trees generated after a heuristic search using the elongation factor 1- $\alpha$ DNA sequence data with ambiguous and missing data excluded. Branch length values are shown above the tree branches and percentage bootstrap (1000 replicates) values greater than $50 \%$ are shown below the tree branches. Number of parsimony informative characters $=173$, tree length $=314$ steps, $\mathrm{CI}=0.787$ and $\mathrm{RI}=0.897$.

Isolates within the A. mellea clade formed strongly supported monophyletic groups consistent with the geographical origin of the isolates. These were isolates from
Asia, Europe, eastern North American and western North America. Differences between geographically separated isolates of A. mellea have been observed in a number 
of previous studies. Anderson et al. (1989) showed that A. mellea isolates from Europe and eastern North America differ in their EcoRI, BamHI and SalI digestion patterns of the rRNA operon. Intraspecies variation pertaining to IGS-1 RFLP patterns was similarly reported for this species by Harrington and Wingfield (1995). Likewise, differences have been observed in the mating systems of isolates from Europe, North America and Japan (Anderson et al. 1980; Ota etal. 1998). The subdivision of isolates of A. mellea according to their origin is congruent with the study of Coetzee et al. (2000a), showing that isolates of $A$. mellea from various Northern Hemisphere origins represent Asian, European, eastern North American and western North American lineages. Of these, isolates from Europe, North America and Asia have been shown to be sexually compatible and thus reported to be the same biological species (Anderson et al. 1980, 1989; Ota et al. 1998). The separation of the isolates into geographic groups may reflect intraspecific variation due to allopatric separation. Alternatively, these lineages may represent sibling species in the process of allopatric speciation (Coetzee et al. 2000a) with incompletely developed intrinsic genetic isolation mechanisms. Inclusion of sequence data from a gene region not previously considered, adds strong additional support for the view that $A$. mellea from different geographic areas are genetically distinct and probably represent sibling species.

Results of this study showed that isolates in the A. ostoyae clade included those representing $A$. ostoyae and A. gallica. Armillaria ostoyae and $A$. gemina, have previously shown to be phylogenetically closely related (Anderson and Stasovski 1992; Miller et al. 1994). These two species also have identical basidiocarp morphology (Bérubé and Dessureault 1989). They can however, be differentiated from other species based on vegetative features (Bérubé and Dessureault 1989) and on mating tests (Anderson and Ullrich 1979).

Isolates representing $A$. borealis, $A$. gallica, $A$. nabsnona, A. cepistipes and A. tabescens grouped in the A. gallica clade. These data are congruent with studies showing that A. gallica and A. cepistipes are ecologically (Korhonen 1995) and morphologically (Termorshuizen and Arnolds 1987; Marxmüller 1992; Korhonen 1995) similar and that they can only be differentiated using mating tests (Termorshuizen and Arnolds 1987). They are also consistent with the fact that A. gallica and $A$. cepistipes have previously been shown to be phylogenetically closely related based on DNA data (Anderson and Stasovski 1992; Miller et al. 1994; Chillali et al. 1998). Furthermore, A. nabsnona has been found to be related to $A$. gallica based on DNA reassociation data (Miller et al. 1994) and our new sequence data confirm this view.

The grouping of $A$. borealis in the A. gallica clade in this study is an interesting result. Previous studies based on ITS and IGS-1 sequence data analysis of the rDNA operon showed that this species is phylogenetically most closely related to A. ostoyae and A. gemina (Anderson and
Stasovski 1992; Chillali et al. 1998). Also, Korhonen (1995) placed $A$. borealis within the 'A. ostoyae clade' based on morphological similarities with $A$. ostoyae and A. gemina. The lack of correlation between the ribosomal phylogeny and that of the EF 1- $\alpha$ gene suggests that the evolutionary histories of these two gene regions are not the same. This highlights the danger of using single gene phylogenies to infer phylogenetic relationships.

The grouping of $A$. tabescens within the A. gallica clade was unexpected. Previous work based on DNA reassociation showed that A. mellea and A. tabescens are most closely related (Miller et al. 1994). Chillali et al. (1998) further showed, using ITS sequence data, that $A$. mellea and A. tabescens are basal to the rest of Northern Hemisphere species. Miller et al. (1994) contended that A. tabescens is the more basal species and, therefore, more ancient than A. mellea. These studies, however, did not include species from the Southern Hemisphere. The grouping of $A$. tabescens with A. gallica, A. cepistipes and A. nabsnona may be explained by the different rates at which ribosomal and protein-coding genes evolve. The different evolutionary rates lead to these species grouping together in one way when ribosomal genes are used and in another way when proteincoding genes are employed, as was observed in this study.

Armillaria fumosa, A. pallidula, A. novae-zelandiae, A. luteobubalina, A. limonea, A. hinnulea and the undescribed species from New Zealand have been reported only from the Southern Hemisphere (Kile and Watling 1983, 1988). Cladograms generated from EF1- $\alpha$ sequences confirm that these species are closely related and that they group basal to those from the Northern Hemisphere. This is consistent with the results of previous studies based on IGS-1 and LSU sequence data, suggesting that the Southern Hemisphere species are ancestral to those from the Northern Hemisphere (Coetzee et al. 2001; Dunne et al. 2002). The new sequence dataset, therefore, provides further evidence for the hypothesis that Armillaria or the ancestor of this genus originated in Gondwana (Coetzee et al. 2001; Dunne et al. 2002).

Armillaria fumosa and A. pallidula grouped together in a one clade in this study. This supports the findings of Coetzee et al. (2001) who reported that these species are closely related and cannot be distinguished using ITS sequence information. Kile and Watling (1988), using interfertility tests and morphology, showed that these are distinct species although they share some morphological similarities. The results of the present study together with those of Coetzee et al. (2001) indicate that the species have recently diverged from a common ancestor and have not accumulated sufficient differences at the DNA level to differentiate between them.

The grouping of $A$. hinnulea outside the Northern Hemisphere clade in this study was of particular interest. This species has been reported from Tasmania, southeast Australia and New Zealand and it is to be expected that it 
should be phylogenetically closely related to those species occurring in the Southern Hemisphere. Phylogenetic studies based on ITS sequence data, however, showed that it is most closely related to species from the Northern Hemisphere (Coetzee et al. 2001; Dunne et al. 2002). Dunne et al. (2002) suggested that it may have evolved from a common ancestor with $A$. cepistipes [ $=$ A. bulbosa]. This result is supported by the findings of Kile and Watling (1983), who showed that the basidiocarp morphology of $A$. hinnulea is in various aspects similar to those of the European species $A$. cepistipes. The fact that the EF 1- $\alpha$ gene sequences gave results different from those from studies based on the ITS region might reflect the fact that EF 1- $\alpha$ has evolved more slowly than the ITS region. More rapid evolution of the ITS region could have resulted in the inclusion of synapomorphic characters, leading to A. hinnulea grouping with Northern Hemisphere species. In contrast, the EF $1-\alpha$ gene nucleotides for this species may have retained the ancestral character states of species in the Southern Hemisphere, resulting in the grouping of this species basal to those from the Northern Hemisphere.

Isolates representing $A$. luteobubalina from Chile and Australia had similar DNA sequences and grouped together in one clade. An isolate, tentatively identified as A. luteobubalina based on IGS-1 and ITS sequences (Coetzee et al. 2003), grouped with the isolates representing this species. The identification of this isolate as A. luteobubalina has been controversial, as this species had never before been reported from South America. Results of the current study provide additional evidence that the isolates from Chile represent A. luteobubalina and that the species is present in South America. Coetzee et al. (2003) also showed that despite their large geographic separation, isolates in this clade retained a high level of ITS and IGS-1 sequence similarity. These authors therefore postulated that this is an ancient species with its origin in the Gondwana supercontinent.

Phylogenetic trees obtained in this study showed that $A$. luteobubalina is closely related to A. limonea. Isolates representing the latter species grouped in a monophyletic clade. This relationship supports the findings of Kile and Watling (1988) that the two species share some morphological characters such as a yellow pigment in their pileus.

An unidentified isolate from Indonesia grouped with A. novae-zelandiae in a strongly supported clade. This isolate represents a set of isolates that were obtained from infected Eucalyptus grandis trees but for which no basidiocarps were found. A description based on morphology or identification using mating tests was thus not possible (Coetzee et al. 2003). The set of isolates were considered by Coetzee et al. (2003) who attempted to identify them. In their study the authors showed that the isolates either represent $A$. novae-zelandiae or a previously undescribed species that is closely related to that species. The phylogenetic trees generated in this study thus support the finding of Coetzee et al. (2003).
Armillaria novae-zelandiae is common in New Zealand and Australia (Kile and Watling 1983). Isolates from both areas appear to represent a single species (Coetzee et al. 2001). These isolates are morphologically similar (Kile and Watling 1983) and are sexually compatible (Kile and Watling 1983). Our results using sequence data from a new gene region support the view that these isolates represent the same taxon.

Two undescribed isolates from New Zealand formed a distinct clade and showed no relationship to any known species, but fell in the Southern Hemisphere group. These isolates were shown by Coetzee et al. (2001) to probably represent an undescribed species. Results of the present study provide additional support for the view that these isolates represent a discrete taxon that awaits description.

This study presents the first EF 1- $\alpha$ DNA sequence data for Armillaria species. It is also the first protein-coding gene and first single-copy gene to be investigated for phylogenetic analysis of this genus. Sequence data from the majority of isolates belonging to the different species showed unique species-specific substitutions, allowing the isolates to be differentiated into clades representing the species. Results of this study demonstrate that the EF $1-\alpha$ region is useful for phylogenetic analysis and classification of Armillaria species. They have also added considerable confidence to relationships identified based on DNA sequences for other gene regions.

\section{Acknowledgements}

We are very grateful to members of the Tree Protection Co-operative Programme (TPCP), the National Research Foundation (NRF), the THRIP initiative of the Department of Trade and Industry and the DST/NRF Center of Excellence in Tree Health Biotechnology (CTHB) South Africa for financial assistance.

\section{References}

Anderson JB, Stasovski E (1992) Molecular phylogeny of Northern Hemisphere species of Armillaria. Mycologia 84, 505-516.

Anderson JB, Ullrich RC (1979) Biological species of Armillaria mellea in North America. Mycologia 71, 402-414.

Anderson JB, Korhonen K, Ullrich RC (1980) Relationships between European and North American biological species of Armillaria mellea. Experimental Mycology 4, 78-86. doi: 10.1016/01475975(80)90053-5

Anderson JB, Bailey SS, Pukkila PJ (1989) Variation in ribosomal DNA among biological species of Armillaria, a genus of root-infecting fungi. Evolution 43, 1652-1662. doi: 10.2307/2409381

Baayen RP, O’Donnell K, Bonants PJM, Cigelnik E, Kroon LPNM, Roebroeck JA, Waalwijk C (2000) Gene genealogies and AFLP analysis in the Fusarium oxysporium complex identify monophyletic and nonmonophyletic formae speciales causing wilt and root disease. Phytopathology 90, 891-900.

Bérubé JA, Dessureault M(1989) Morphological studies of the $A$. mellea complex: two new species, A. gemina and A. calvescens. Mycologia 81, 216-225. 
Burdsall HH, Banik M, Cook ME (1990) Serological differences of three species of Armillaria and Lentinula edodes by enzyme-linked immunosorbent assay using immunized chickens as sources of antibodies. Mycologia 82, 415-423.

Chillali M, Idder-Ighil H, Guillaumin J-J, Mohammed C, Escarmant BL, Botton B (1998) Variation in the ITS and IGS regions of ribosomal DNA among the biological species of European Armillaria. Mycological Research 102, 533-540. doi: 10.1017/ S0953756297005315

Coetzee MPA, Wingfield BD, Harrington TC, Dalevi D, Coutinho TA, Wingfield MJ (2000a) Geographic diversity of Armillaria mellea s.s based on phylogenetic analysis. Mycologia 92, 105-113.

Coetzee MPA, Wingfield BD, Coutinho TA, Wingfield MJ (2000b) Identification of the casual agent of Armillaria root rot of Pinus species in South Africa. Mycologia 92, 777-785.

Coetzee MPA, Wingfield BD, Bloomer P, Ridley GS, Kile GA, Wingfield MJ (2001) Phylogenetic relationships of Australian and New Zealand Armillaria species. Mycologia 93, 887-896.

Coetzee MPA, Wingfield BD, Bloomer P, Ridley GS, Wingfield MJ (2003) Molecular identification and phylogeny of Armillaria isolates from South America and Indo-Malaysia. Mycologia 95, 285-293.

Coetzee MPA, Wingfield BD, Bloomer P, Wingfield MJ (2005) Phylogenetic analyses of DNA sequences reveal species partitions amongst isolates of Armillaria from Africa. Mycological Research 109, 1223-1234. doi: 10.1017/S095375620500393X

Dunne CP, Glen M, Tommerup IC, Shearer BL, Hardy GESt J (2002) Sequence variation in the rDNA ITS of Australian Armillaria species and intra-specific variation in A. luteobubalina. Australasian Plant Pathology 31, 241-251. doi: 10.1071/AP02015

Felsenstein J (1985) Confidence limits on phylogenies: an approach using bootstrap. Evolution 39, 783-791. doi: 10.2307/2408678

Harrington TC, Wingfield BD (1995) A PCR-based identification method for species of Armillaria. Mycologia 87, 280-288.

Hillis DM, Huelsenbeck JP (1992) Signal, noise, and reliability in molecular phylogenetic analysis. The Journal of Heredity 83, 189-195.

Jiménez-Gasco MM, Milgroom MG, Diaz-Jimenez RM (2002) Gene genealogies support Fusarium oxysporum f.sp. ciceris as a monophyletic group. Plant Pathology 51, 72-77. doi: 10.1046/ j.0032-0862.2001.x

Kauserud H, Schumacher T (2001) Outcrossing or inbreeding: DNA markers provide evidence for type of reproductive mode in Phellinus nigrolimitatus (Basidiomycota). Mycological Research 53, 220-230.

Kile GA, Watling R (1981) An expanded concept of Armillaria luteobubalina. Transactions of the British Mycological Society 81, 129-140.

Kile GA, Watling R (1983) Armillaria species from SouthEastern Australia. Transactions of the British Mycological Society 81, 129-140.

Kile GA, Watling R (1988) Identification and occurrence of Australian Armillaria species, including A. pallidula sp. nov. and comparative studies between them and non-Australian tropical and Indian Armillaria. Transactions of the British Mycological Society 91, 305-315.

Korhonen K (1978) Interfertility and clonal size in the Armillariella mellea complex. Karstenia 18, 31-42.

Korhonen K (1995) Armillaria since Elias Fries. Acta Universitatis Upsaliensis. Symbolae Botanicae Upsalienses 30, 153-161.

Lin D, Duma MT, Hubbes M (1989) Isozyme and general protein patterns of Armillaria spp. collected from the boreal mixed wood forest of Ontario. Canadian Journal of Botany 67, 1143-1177.
Maniatis T, Fritsch EF, Sambrook J (1982) 'Molecular cloning: a laboratory manual.' (Cold Spring Harbour Laboratory: Cold Spring Harbour, NY)

Marxmüller H (1992) Some notes on the taxonomy and nomenclature of five European Armillaria species. Mycotaxon 44, 267-274.

Miller OK, Johnson JL, Burdsall HH, Flynn T (1994) Species delimitation in North American species of Armillaria as measured by DNA reassociation. Mycological Research 98, 1005-1011.

Mohammed C, Guillaumin J-J, Berthelay S (1989) Preliminary investigations about the taxonomy and genetics of African Armillaria species. In 'Proceedings of the 7th International Conference on Root and Butt Rots, 1988'. (Ed. DJ Morrison) pp. 447-457. (International Union of Forest Research Organizations: Vernon and Victoria, BC)

Morrison DJ, Thomson DC, Peet FG, Sahota TS, Rink U (1985) Isozyme patterns of Armillaria intersterility groups in British Columbia. Canadian Journal of Botany 31, 651-653.

Mwenje E, Ride JP (1996) Morphological and biochemical characterisation of Armillaria isolates from Zimbabwe. Plant Pathology 45, 1036-1051. doi: 10.1046/j.1365-3059.1996.d01184.x

Mwenje E, Ride JP (1997) The use of pectic enzymes in the characterization of Armillaria isolates from Africa. Plant Pathology 46, 341-354. doi: 10.1046/j.1365-3059.1997.d01-30.x

Mwenje E, Wingfield BD, Coetzee MPA, Wingfield MJ (2003) Molecular characterization of Armillaria species from Zimbabwe. Mycological Research 107, 291-296. doi: 10.1017/ S0953756203007408

Ota Y, Matsushita N, Nagasawa E, Terashita T, Fukuda K, Suzuki K (1998) Biological species of Armillaria in Japan. Plant Disease 82, 537-543.

Pérez-Sierra A, Guillaumin J-J, Spooner BM, Bridge PD (2004) Characterization of Armillaria heimii from Africa. Plant Pathology 53, 220-230. doi: 10.1111/j.0032-0862.2004.00999.x

Piercey-Normore MD, Egger KN, Bérubé JA (1998) Molecular phylogeny and evolutionary divergence of North American Biological Species of Armillaria. Molecular Phylogenetics and Evolution 10, 49-66. doi: 10.1006/mpev.1997.0485

Slobin LI (1980) The role of eukaryotic elongation factor $\mathrm{Tu}$ in protein synthesis. European Journal of Biochemistry 110, 555-563. doi: 10.1111/j.1432-1033.1980.tb04898.x

Swift MJ (1972) The ecology of Armillaria mellea (Vahl ex Fries) in indigenous and exotic woodlands of Rhodesia. Forestry 45, 67-86.

Swofford DL (1998) 'PAUP*: Phylogenetic analysis using parsimony (*and other methods). Version 4.' (Sinauer Associates: Sunderland, MA)

Termorshuizen A, Arnolds E (1987) On the nomenclature of the European species of the Armillaria mellea group. Mycotaxon 30, 101-116.

Thompson JD, Gibson TJ, Plewniak F, Jeanmougin F, Higgins DG (1997) The ClustalX windows interface: flexible strategies for multiple sequence alignment aided by quality analysis tools. Nucleic Acids Research 25, 4876-4882. doi: 10.1093/nar/25.24.4876

Ullrich RC, Anderson JB (1978) Sex and diploidy in Armillaria mellea. Experimental Mycology 2, 119-129. doi: 10.1016/S01475975(78)80025-5

Volk TJ, Burdsall HH (1995). 'A nomenclatural study of Armillaria and Armillariella species.' (Synopsis Fungorum 8: Førde)

Whalström K, Karlsson JO, Holdenrieder O, Stenlid J (1991) Pectinolytic activity and isozymes in European Armillaria species. Canadian Journal of Botany 69, 2732-2739.

Received 22 September 2005, accepted 26 June 2006 